\title{
Impact of Protein Source and Its Levels on Egg Production and Egg Quality of Japanese Quail (Coturnix coturnix japonica)
}

\author{
Jameela H. Salih a, Dejeen A. Mohammed ${ }^{\text {a }}$, Shekhmous H. Hussen ${ }^{\text {a,* }}$ \\ ${ }^{a}$ Dept. of Animal Production, College of Agricultural Engineering Sciences, University of Duhok, Kurdistan Region - Iraq, \\ (sheikhmous.hussein@uod.ac)
}

\begin{abstract}
:
Fish and soybean meal are known as common utilized crude protein sources in poultry diets. Quail birds often need higher requirements of dietary protein which influences its productive performance. The aim of the experiment is to determine the impact of protein source with different levels on egg production and egg quality characteristics. The experiment was carried out at animal production dept., University of Duhok, Kurdistan Region- Iraq, during spring 2020 for 56 days. The birds were divided into two main groups (fish meal and soybean meal) with three levels of crude protein (CP) as sub groups $(20 \%, 23 \%$ and $26 \%)$. At 35 days of age, 240 quails were sexed and distributed on wire cages as four replications for each protein level within each group (treatment) as family ( 8 pullets with 2 cocks). The investigated characters were; Egg weight (EW), egg number (EN), egg mass (EM), egg quality characteristics (shape index, high, weight and diameter of both, yolk and albumen, egg shell thickness and weight and Haugh units); feed intake (FI), feed conversion ratio (FCR), hatchability and fertility percentage. The main results were as follows; EW, EM and most of egg quality characteristics did not show significant difference $(\mathrm{P}>0.05)$ either by source of protein or its levels; also, FI and FCR did not differ significantly $(\mathrm{P}>0.05)$ by the effect of protein source; while EN, FI and FCR were affected significantly $(\mathrm{P} \leq 0.05)$ by $\mathrm{CP}$ level. To conclude, there was no obvious trend for the effect of both $\mathrm{CP}$ source and level on early egg yield and egg quality in J. quail.
\end{abstract}

KEYWORDS: Japanese quail, protein source, protein level, egg production, egg quality.

\section{INTRODUCTION}

Japanese quails (Coturnix coturnix japonica) birds are mainly raised for producing eggs and meat purposes, in addition to their benefits as experimental animals because of their small size, early sexual maturity, having high breeding efficiency and are raised easily (Wilson et al., 1961). The quail prefers and requires a high protein level in the diet for optimum growth and reproduction (Shim and Vohra, 1984). The protein level of hen's diet is one of the major factors affecting egg yield and egg characteristics; different references indicated different optimum level of crude protein in layer diet of quail $(20 \%$ of both soybean or fish meal (NRC, 1985; Minoguchi et al., 2000; $22 \%$ of soybean or fish meal - Ohguchi et al., 1997). Some researchers reported that the increase in egg number and weight is related directly to the increase in dietary protein levels (Gunawardana et al., 2008; King'ori et al., 2010; MohitiAsli et al., 2012; Shim et al., 2013). On the other hand, some investigators reported that egg production was not influenced by low dietary protein level (Cho et al., 2004; Khajali et al., 2008). A protein deficiency often caused by either one or more limiting amino acids or an overall inadequate consumption of protein, which resulted in decreasing in performance parameters; and feed consumption and utilization (Church, 1991). Eishu et al., (2005), used both sources of crude protein (soybean and fish meals) in layer quails with different levels from 16 up to $26 \%$; they found that the egg production traits were increased linearly by increasing the protein level from 6 up to 32 weeks old; while the egg quality traits did not have the same trend.
However, Yalcin et al. (2007) reported that quail birds fed $19.40 \%$ dietary protein with 12.53 MJ Metabolizable energy $/ \mathrm{kg}$ diet during the laying period from 9-21 weeks old recorded average hen day egg production of $80.40 \%$. In addition Fernando et al. (2008) found that quail hens fed $20 \%$ dietary protein with $2900 \mathrm{kcal}$ Metabolizable energy/kg diet during laying period from 13-28 weeks old resulted in average hen day egg production of $72.30 \%$. Dahouda et al., (2013) studied protein source (fishmeal and soybean meal) impacts with two levels (20 and $25 \%$ ) on the performance of layer quails, and indicated that the best optimal incorporation level was $20 \%$ in the diet irrespective to the source. Salih and Hussen, (2018), stated that the Japanese quail birds that fed soybean meal as source of protein with different levels according to the type of ration (starter 26, grower 21 and breeder $15.7 \%$ ) resulted in mean egg weight of $10.44 \mathrm{gm}$., during the first two weeks of laying period. Also, Salih, 2016, reported that the average of nine quail genotypes that fed $15.7 \%$ soybean meal crude protein in laying period resulted in sexual maturity of 41.7 days and egg mass with mean of $50.9 \mathrm{gm}$., for the second week of production; the author pointed that feed conversion ratio of laying period was worse and not as expected.

The present study aimed to illustrate the effect of two protein sources with three levels for each, on the laying performance and egg quality of Japanese quail.

* Corresponding author

This is an open access under a CC BY-NC-SA 4.0 license (https://creativecommons.org/licenses/by-nc-sa/4.0/) 


\section{MATERIAL AND METHODS}

\subsection{Management and rearing}

The study was conducted at poultry farm in Duhok city/College of Agricultural Engineering Sciences/Animal production department/ Kurdistan Region, Iraq. A total of 360 one-day unsexed quail chicks were divided equally into two treatments of different source of protein (fish meal and soybean meal); within each treatment, three levels of dietary crude protein of $20 \%, 23 \%$ and $26 \%$, respectively were applied as second experimental factor, until 56 days of age for laying performance. At 35 days old, 240 birds were sexed and redistributed on cages with three replicates for each protein levels within each treatment separately as families ( 8 females with 2 males). Water and food were submitted ad-libitum. The daily ambient temperature $\left(\mathrm{C}^{\circ}\right)$ and relative humidity $(\%)$ were measured during the experimental period in spring 2020, for 56 successive days, that are illustrated in Figure 1. The submitted dietary rations according to the fed treatments and its levels are presented in Table 1. The light was provided for 15 hour / day during laying period.

\subsection{Studied traits and parameters}

The studied traits were; early Egg weight (EW), egg number (EN), egg mass (EM), egg quality characteristics involved (shape index, height, weight and diameter of both yolk and albumen, egg shell thickness and weight (which were measured using sensitive digital balance with accuracy of $0.0001 \mathrm{gm}$. and slide calipers accuracy of $0.1 \mathrm{~mm}$ ) and, feed intake, feed conversion ratio, hatchability and fertility percentage. Egg production was monitored every day from 42 days old, for two successive weeks. However, feed conversion ratio (FCR) was calculated according to the following formula:

$\mathrm{FCR}=$ Feed intake (during a certain period) $/$ egg mass (during the same period)
And egg mass was computed according to the following formula:

$\mathrm{EM}(\mathrm{gm})=$ Egg number $($ in a certain period $) *$ Average egg weight (in the same period)

Regarding external and internal egg quality, the eggs were collected weighed and their length and width were measured to calculate their shape index (Shape index $=($ Width $/$ length) *100), then the eggs were broken to measure their albumen and yolk heights and diameters; the yolk separated from albumen to be weighed; and also the eggshells were weighed; while the albumen weights were calculated by the difference (Albumen weight $=$ Egg weight $-($ yolk weight + Eggshell weight $)$. Haugh units were computed according to the following formula:

Haugh Unit $=100 \log [($ albumen height $)+7.57-1.7 *$ egg weight ${ }^{0.37}$ ]

The eggshell thickness of dried eggs in $(\mathrm{mm})$ was measured by using the digital caliper.

\subsection{Statistical Analysis}

Collected data were analyzed as factorial experiment $(2 \times 3)$ conducted with completely randomized design with two factors and three levels, using SAS software (SAS Institute, 2014) applied with GLM model.

$$
Y_{i j}=\mu+S i+L j+(S * L)_{i j}+e_{i j k}
$$

Where: Yij: the studied trait; $\mu=$ over all mean; $\mathrm{Si}$ : The fixed effect of source of protein; $\mathrm{Lj}$; level of protein; $\left(\mathrm{S}^{*} \mathrm{~L}\right) \mathrm{ij}$ : the interaction between source and level; $\boldsymbol{e}_{i j k}=$ random error.

The differences among means were tested using Duncan multiple range test (Duncan, 1955).

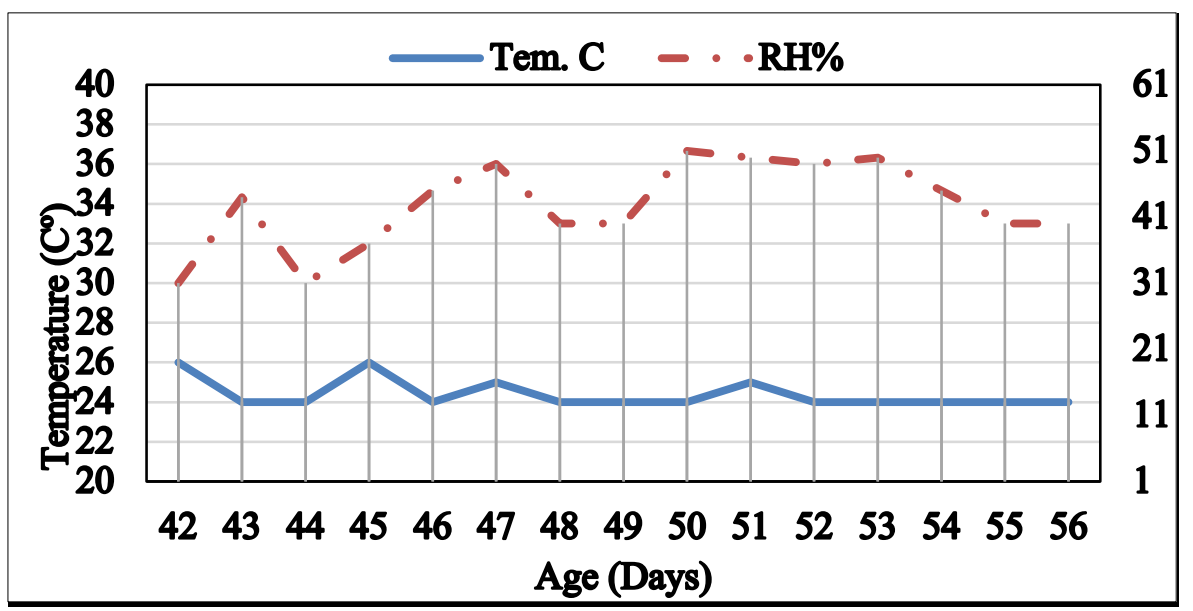

Figure 1. Daily Temperature $\left(\mathrm{C}^{\circ}\right)$ and Relative Humidity (\%) during laying period 
Table 1. Dietary rations fed to the quail hens during the experiment

\begin{tabular}{|l|c|c|c|c|c|c|}
\hline \multirow{2}{*}{ Ingredient } & \multicolumn{3}{c|}{ Fish-meal protein } & \multicolumn{3}{c|}{ Soybean-meal protein } \\
\cline { 2 - 7 } & $\mathbf{2 0}(\mathbf{\%})$ & $\mathbf{2 3}(\mathbf{\%})$ & $\mathbf{2 6}(\mathbf{\%})$ & $\mathbf{2 0}(\mathbf{\%})$ & $\mathbf{2 3}(\mathbf{\%})$ & $\mathbf{2 6}(\mathbf{\%})$ \\
\hline Yellow corn & 61 & 55 & 50 & 52 & 42 & 34 \\
\hline Soybean meal (48\%) & - & - & - & 30 & 39 & 47 \\
\hline Fish meal (60\%) & 19 & 25 & 30 & - & - & - \\
\hline Wheat grain & 11 & 11 & 11 & 9 & 10 & 10 \\
\hline Wheat bran & 4 & 4 & 4 & 4 & 4 & 4 \\
\hline Vegetable oil & 2 & 2 & 2 & 2 & 2 & 2 \\
\hline Limestone & 2.1 & 21.1 & 2.1 & 2.1 & 2.1 & 2.1 \\
\hline Di-calcium phosphate & 0.1 & 0.1 & 0.1 & 0.1 & 0.1 & 0.1 \\
\hline Mixture vit. \& Min. & 0.3 & 0.3 & 0.3 & 0.3 & 0.3 & 0.3 \\
\hline Salt & 0.5 & 0.5 & 0.5 & 0.5 & 0.5 & 0.5 \\
\hline Total & $\mathbf{1 0 0}$ & $\mathbf{1 0 0}$ & $\mathbf{1 0 0}$ & $\mathbf{1 0 0}$ & $\mathbf{1 0 0}$ & $\mathbf{1 0 0}$ \\
\hline Chemical composition & \multicolumn{3}{|c|}{} & & \multicolumn{2}{|c|}{} \\
\hline ME (k.cal./kg) & 3130 & 3099 & 3073 & 2904 & 2798 & 2708 \\
\hline CP (\%) & 19.8 & 23.07 & 25.82 & 19.83 & 23.05 & 25.9 \\
\hline C. Fiber (\%) & 2.25 & 2.15 & 2.1 & 4.1 & 4.6 & 4.9 \\
\hline Ether extract & 6.44 & 6.77 & 7 & 4.5 & 4.25 & 4.01 \\
\hline Methionine & 0.34 & 0.39 & 0.43 & 0.33 & 0.37 & 0.4 \\
\hline Lysine & 0.84 & 1.02 & 1.2 & 1.07 & 1.3 & 1.5 \\
\hline
\end{tabular}

\subsection{Egg Production}

\section{RESULTS AND DISCUSSION}

Egg production characteristics of quail fed different protein sources with different levels are presented in Table 2. There is no significant $(\mathrm{P}>0.05)$ effect of protein source on the studied characteristics. While the effect of protein level within protein source was significant $(\mathrm{P} \leq 0.05)$ for both egg number and egg mass traits; where the intermediate level of $23 \%$ has the highest values compared to the first studied level (20\%); but as comparison between the level of $23 \%$ and $26 \%$, the results showed insignificant differences (Table 2); such results are in favor of adopting the level of $23 \%$ in the quail diets instead of $26 \%$ for egg production traits, due to the economic efficiency. Regarding the interaction between protein source and level, it could be observed from the mentioned table, that just EN was interacted significantly $(\mathrm{P} \leq 0.05)$; where the highest value (52.33 eggs) was recorded for Soybean at $23 \%$ level and the lowest one was recorded for the same source at $20 \%$ level (33 eggs). These results indicate that the protein level plays a better role than its source. These findings are in agreement with the results of (Shim and Vohra, 1984; NRC, 1985; Minoguchi et al., 2000); they reported the importance of protein level.

Table 2. Means \pm SE of Egg production traits as affected by protein source, level and their interaction (eggs/hen/week)

\begin{tabular}{|c|c|c|c|c|c|c|c|c|}
\hline \multirow{2}{*}{$\begin{array}{c}\text { Trai } \\
\mathbf{t}\end{array}$} & \multirow{2}{*}{ Source (S) } & \multicolumn{3}{|c|}{ Levels (L) } & \multirow{2}{*}{$\begin{array}{c}\text { Overall } \\
\text { Mean / (Source) }\end{array}$} & \multicolumn{3}{|c|}{ Sig. $(p)$} \\
\hline & & 20 & 23 & 26 & & $\mathbf{S}$ & $\mathbf{L}$ & $S * L$ \\
\hline \multirow{3}{*}{ EN } & Fish meal & $43.66 \pm 1.33^{b}$ & $46.33 \pm 5.66^{\mathrm{b}}$ & $45.33 \pm 1.33^{b}$ & $45.11 \pm 1.76$ & \multirow{3}{*}{ ns } & \multirow{3}{*}{$*$} & \multirow{3}{*}{ * } \\
\hline & Soybean & $33.00 \pm 1.52^{\mathrm{c}}$ & $\mathbf{5 2 . 3 3} \pm 0.88^{\text {a }}$ & $44.00 \pm 3.51^{b}$ & $43.11 \pm 3.0$ & & & \\
\hline & $\begin{array}{c}\text { Overall mean / } \\
\text { (Level) }\end{array}$ & $38.33 \pm 2.55^{\mathrm{A}}$ & $49.33 \pm 2.89^{\mathrm{A}}$ & $44.66 \pm 1.70 \mathrm{AB}$ & & & & \\
\hline \multirow{3}{*}{ EW } & Fish meal & $10.31 \pm 0.21$ & $10.18 \pm 0.07$ & $10.32 \pm 0.11$ & $10.27 \pm 0.07$ & \multirow{3}{*}{ ns } & \multirow{3}{*}{$\mathrm{ns}$} & \multirow{3}{*}{ ns } \\
\hline & Soybean & $10.59 \pm 0.11$ & $10.12 \pm 0.09$ & $10.11 \pm 0.07$ & $10.28 \pm 0.09$ & & & \\
\hline & $\begin{array}{c}\text { Overall mean/ } \\
\text { level }\end{array}$ & $10.45 \pm 0.12$ & $10.15 \pm 0.05$ & $10.21 \pm 0.07$ & & & & \\
\hline \multirow{3}{*}{ EM } & Fish meal & $64.52 \pm 3.25$ & $67.28 \pm 8.02$ & $67.15 \pm 1.42$ & $66.32 \pm 2.57$ & \multirow{3}{*}{ ns } & \multirow{3}{*}{$*$} & \multirow{3}{*}{$\mathrm{ns}$} \\
\hline & Soybean & $49.99 \pm 2.73$ & $75.88 \pm 1.45$ & $63.74 \pm 5.45$ & $63.21 \pm 4.15$ & & & \\
\hline & $\begin{array}{c}\text { Overall mean/ } \\
\text { level }\end{array}$ & $57.26 \pm 3.76^{\mathrm{B}}$ & $71.58 \pm 4.12^{\mathrm{A}}$ & $65.45 \pm 2.63 \mathrm{AB}$ & & & & \\
\hline
\end{tabular}

Different superscript small letters $(a, b, c .$.$) differ significantly for the interaction between source and level; and different capital$ superscript letters $(A, B, C \ldots)$ differ significantly for level effect. *- significant at 0.05 level; $n s=n o n$-significant

\subsection{Egg Quality}

Table 3, presents the egg quality characteristics as affected by the studied protein source and its levels. It seems from the table that most studied characters are not affected significantly $(p>0.05)$ by the studied factors. However, from the same table, it could be seen that just two traits (EW and YD) are affected significantly $(\mathrm{P} \leq 0.05)$ by the protein source; where the fish meal source surpassed soybean one in both studied traits. These results indicate that the weight of Japanese quail egg may be related to its yolk diameter and both of them are affected positively with fish meal protein more than soybean meal, which could be due to specific amino acids in fish meal diet such as methionine or lysine that is insufficient in soybean.

Regarding the effect of protein level within each protein source, it could be observed from the previous table that just EW and 
AlW are significant $(\mathrm{P} \leq 0.05)$, where the low level of $20 \%$ surpassed both 23 and $26 \% \mathrm{CP}$. These findings may reflect the low requirements of layer hens of quail to CP.

In respect to the interaction between source of protein and its level, the same table indicates that just AlW has interacted significantly $(\mathrm{P} \leq 0.05)$, where the fish meal with $26 \%$ resulted in the highest value and, on the contrary, the soybean at the same level resulted in the lowest value. This mean that for laying stage of quail may apply fish meal with high level to produce eggs with high weight of albumen which will affect positively on egg weight.

However, some factors could have an effect on the egg quality traits such as; live body weight, line, season, and some environment factors such as relative humidity (Narushin, and Romanov, 2002; Khurshid, et al., 2003). Moreover, some investigators have indicated that some traits of egg quality has genetic basis and are effected by the genetic variability in dam which is mainly responsible for the hatchability of fertile egg (Song et al., 2000; Wolc, and Olori, 2009).

Table 3: Means \pm SE of the effect of fish meal and soybean meal and their levels on egg quality in Japanese quails

\begin{tabular}{|c|c|c|c|c|c|c|c|c|}
\hline \multirow[b]{2}{*}{ Trait } & \multirow{2}{*}{$\begin{array}{l}\text { Treatment } \\
\text { (Source of } \\
\text { protein) }\end{array}$} & \multicolumn{3}{|c|}{ Levels (L) } & \multirow{2}{*}{$\begin{array}{l}\text { Overall } \\
\text { Mean / } \\
\text { Treatments }\end{array}$} & \multicolumn{3}{|c|}{ Sig. $(p)$} \\
\hline & & 20 & 23 & 26 & & S & $\mathrm{L}$ & S*L \\
\hline \multirow{3}{*}{ Ew } & Fish meal & $10.92 \pm 0.19$ & $10.47 \pm 0.17$ & $10.90 \pm 0.17$ & $10.77 \pm 0.10^{\mathrm{a}}$ & \multirow{3}{*}{ * } & \multirow{3}{*}{$*$} & \multirow{3}{*}{ ns } \\
\hline & Soybean & $10.77 \pm 0.09$ & $10.38 \pm 0.15$ & $10.29 \pm 0.19$ & $10.48 \pm 0.09^{b}$ & & & \\
\hline & $\begin{array}{l}\text { Overall mean/ } \\
\text { level }\end{array}$ & $10.85 \pm 0.11^{A}$ & $10.43 \pm 0.11^{\mathrm{B}}$ & $10.60 \pm 0.13{ }^{\text {в }}$ & & & & \\
\hline \multirow{3}{*}{ ShInd } & Fish meal & $76.66 \pm 0.72$ & $79.71 \pm 1.16$ & $78.12 \pm 0.69$ & $78.16 \pm 0.52$ & \multirow{3}{*}{ ns } & \multirow{3}{*}{ ns } & \multirow{3}{*}{ ns } \\
\hline & Soybean & $79.09 \pm 0.82$ & $78.85 \pm 1.11$ & $79.57 \pm 0.77$ & $79.17 \pm 0.52$ & & & \\
\hline & $\begin{array}{l}\text { Overall mean/ } \\
\text { level }\end{array}$ & $77.87 \pm 0.56$ & $79.28 \pm 0.80$ & $78.84 \pm 0.52$ & & & & \\
\hline \multirow{3}{*}{ YH } & Fish meal & $1.11 \pm 0.01$ & $1.13 \pm 0.01$ & $1.11 \pm 0.01$ & $1.11 \pm 0.01$ & \multirow{3}{*}{ ns } & \multirow{3}{*}{ ns } & \multirow{3}{*}{ ns } \\
\hline & Soybean & $1.13 \pm 0.01$ & $1.13 \pm 0.01$ & $1.13 \pm 0.01$ & $1.13 \pm 0.00$ & & & \\
\hline & $\begin{array}{l}\text { Overall mean/ } \\
\text { level }\end{array}$ & $1.12 \pm 0.01$ & $1.133 \pm 0.01$ & $1.12 \pm 0.01$ & & & & \\
\hline \multirow{3}{*}{ YW } & Fish meal & $3.40 \pm 0.02$ & $3.27 \pm 0.02$ & $3.30 \pm 0.03$ & $3.32 \pm 0.01$ & \multirow{3}{*}{ ns } & \multirow{3}{*}{ ns } & \multirow{3}{*}{ ns } \\
\hline & Soybean & $3.29 \pm 0.02$ & $3.20 \pm 0.01$ & $3.18 \pm 0.03$ & $3.22 \pm 0.01$ & & & \\
\hline & $\begin{array}{l}\text { Overall mean/ } \\
\text { level }\end{array}$ & $3.34 \pm 0.01$ & $3.23 \pm 0.01$ & $3.24 \pm 0.02$ & & & & \\
\hline \multirow{3}{*}{ YD } & Fish meal & $2.17 \pm 0.10$ & $2.18 \pm 0.09$ & $2.22 \pm 0.08$ & $2.19 \pm 0.04^{a}$ & \multirow{3}{*}{$*$} & \multirow{3}{*}{ ns } & \multirow{3}{*}{ ns } \\
\hline & Soybean & $2.14 \pm 0.07$ & $2.12 \pm 0.05$ & $2.10 \pm 0.06$ & $2.12 \pm 0.04^{b}$ & & & \\
\hline & $\begin{array}{l}\text { Overall mean/ } \\
\text { level }\end{array}$ & $2.16 \pm 0.05$ & $2.15 \pm 0.05$ & $2.16 \pm 0.05$ & & & & \\
\hline \multirow{3}{*}{ ALW } & Fish meal & $5.69 \pm 0.01^{\mathrm{b}}$ & $5.38 \pm 0.11^{\mathrm{c}}$ & $5.84 \pm 0.11^{\text {a }}$ & $5.64 \pm 0.06$ & \multirow{3}{*}{$\mathrm{ns}$} & \multirow{3}{*}{ * } & \multirow{3}{*}{ * } \\
\hline & Soybean & $5.68 \pm 0.10^{b}$ & $5.41 \pm 0.12^{c}$ & $5.33 \pm 0.14^{\mathrm{d}}$ & $5.47 \pm 0.07$ & & & \\
\hline & $\begin{array}{l}\text { Overall mean/ } \\
\text { level }\end{array}$ & $5.68 \pm 0.07^{\mathrm{A}}$ & $5.39 \pm 0.08^{\text {B }}$ & $5.58 \pm 0.09^{\text {B }}$ & & & & \\
\hline & Fish meal & $0.49 \pm 0.04$ & $0.48 \pm 0.01$ & $0.45 \pm 0.02$ & $0.47 \pm 0.01$ & & & \\
\hline ALH & Soybean & $0.48 \pm 0.01$ & $0.47 \pm 0.01$ & $0.78 \pm 0.30$ & $0.57 \pm 0.10$ & & & \\
\hline & $\begin{array}{l}\text { Overall mean/ } \\
\text { level }\end{array}$ & $0.48 \pm 0.01$ & $0.47 \pm 0.01$ & $0.61 \pm 0.15$ & & ns & ns & ns \\
\hline & Fish meal & $1.53 \pm 0$ & $1.52 \pm 0.05$ & $1.58 \pm 0.04$ & $1.54 \pm 0.02$ & & & \\
\hline ShW & Soybean & $1.48 \pm 0.01$ & $1.55 \pm 0.05$ & $1.56 \pm 0.04$ & $1.53 \pm 0.02$ & & & \\
\hline & $\begin{array}{l}\text { Overall mean/ } \\
\text { level }\end{array}$ & $1.51 \pm 0.02$ & $1.53 \pm 0.03$ & $1.57 \pm 0.03$ & & ns & ns & ns \\
\hline & Fish meal & $0.10 \pm 0.99$ & $0.10 \pm 0.00$ & $0.10 \pm 0$ & $0.10 \pm 0.00$ & & & \\
\hline & Soybean & $0.10 \pm 0$ & $0.10 \pm 0$ & $0.10 \pm 0$ & $0.10 \pm 01$ & & & \\
\hline ShTh & $\begin{array}{l}\text { Overall mean/ } \\
\text { level }\end{array}$ & $0.10 \pm 01$ & $0.10 \pm 0.00$ & $0.10 \pm 0$ & & ns & ns & ns \\
\hline & Fish meal & $91.87 \pm 0.07$ & $91.77 \pm 0.84$ & $89.55 \pm 1.28$ & $91.06 \pm 0.61$ & & & \\
\hline & Soybean & $91.76 \pm 0.75$ & $91.40 \pm 0.98$ & $95.41 \pm 3.68$ & $92.86 \pm 1.29$ & & & \\
\hline $\mathrm{HU}$ & $\begin{array}{l}\text { Overall mean/ } \\
\text { level }\end{array}$ & $91.81 \pm 0.61$ & $91.58 \pm 0.64$ & $92.48 \pm 1.97$ & & ns & ns & ns \\
\hline
\end{tabular}

Different superscript small letters $(a, b, c$.$) differ significantly for source effect and the interaction between source and level; and$ different capital superscript letters $(A, B, C \ldots)$ differ significantly for level effect. ${ }^{*}$ - significant at 0.05 level; ns=non-significant.

\subsection{Mortality}

Figure 2, illustrates mortality percentage, which is obvious that there is no mortal birds fed both 23 and $26 \% \mathrm{CP}$; while the birds that fed $20 \% \mathrm{CP}$ of both studied sources of protein resulted in the same rate $(10 \%)$; which may reflect the necessary high levels of crude protein in growing periods which may decrease the immunity later in laying age.
However, from statistical point of view, there was insignificant difference $(\mathrm{P}>0.05)$ between both studied sources, and highly significant $(\mathrm{P} \leq 0.01)$ between the lowest level $(20 \%)$ and the other two levels (23 and $26 \%$ ) 


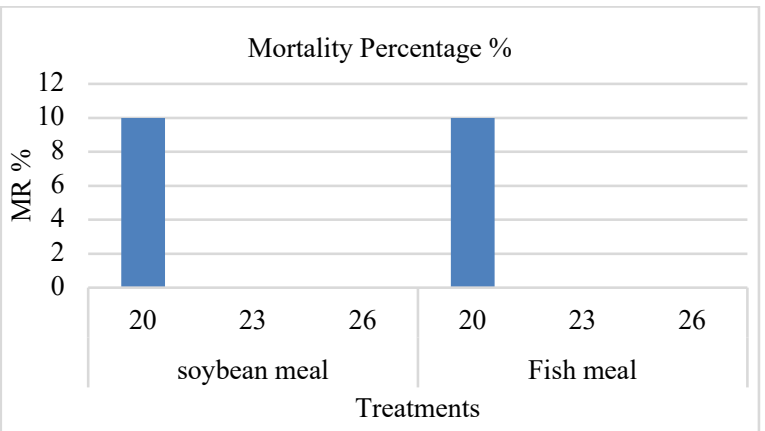

Figure 2. Mortality percentage (\%) during laying period of experiment

\subsection{Feed intake}

It could be seen from Figure 4, that the protein source effect was insignificant $(p>0.05)$, while the effect of level was significant $(\mathrm{P} \leq 0.05)$, where $26 \%$ surpassed significantly $23 \%$ level; but $20 \%$ level recorded the intermediate value. This result has no obvious trend, which could be due to the effect of source of protein, because fish meal in general consumed more than soybean one (but insignificantly). Moreover, the statistical analysis showed insignificant interaction $(\mathrm{P}>0.05)$. Therefore, such finding may be recommended to be analyzed as one-way ANOVA (independent source and level) to result in obvious trend. However, the last method of analysis showed the superiority for fish meal of $26 \% \mathrm{CP}$. This last result insure that quail birds need high level of $\mathrm{CP}$ and prefer fish meal more than soybean one. Moreover, the results reported by Albinon \& Barreto, (2003) and Barreto et al., (2007) determined the feed intake for quail layer as range from $210-231 \mathrm{gm}$ feed intake/bird/week. Also, Mori et al., (2005) recorded averages of $259 \mathrm{gm}$. of feed intake/bird/week at laying period. Berwary et al., (2015) stated that the feed consumed by Japanese quail birds during the period from 12-16 weeks of age was $886 \mathrm{gm}$. / bird/week.

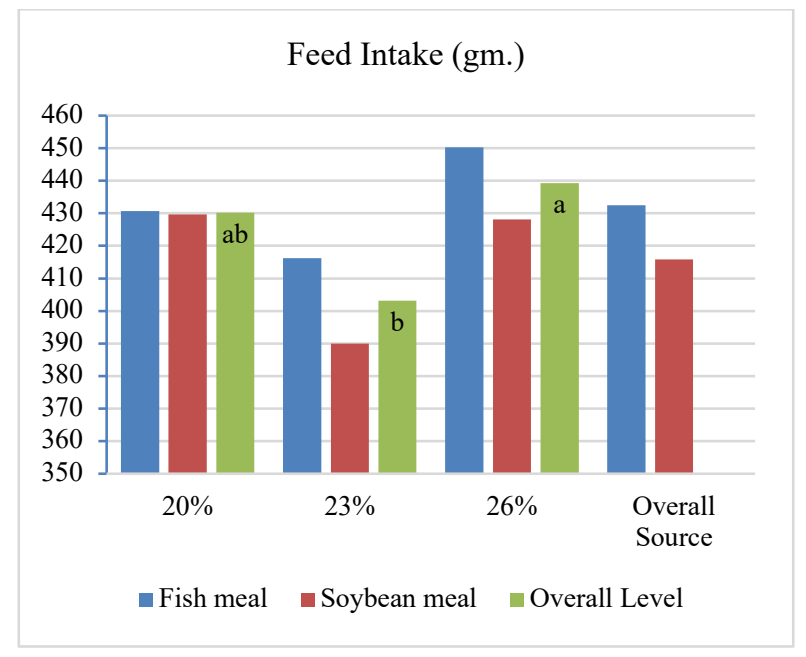

Figure 3. Feed Intake as affected by protein source and levels (for two successive weeks)

\subsection{Feed Conversion ratio}

Figure 4, present the FCR values of quail fed different protein sources with different levels. In contrast to the previous results of feed intake, the figure illustrates that the best significant FCR was recorded for the level of $23 \% \mathrm{CP}$ surpassing $20 \%$ level significantly $(\mathrm{P} \leq 0.05)$, while the level $26 \%$ recorded the intermediate. Also, as mentioned previously in feed intake, the trend in not obvious, which also indicates that the data may be analyzed individually (one-way ANOVA); the last analysis showed that the best FCR was recorded significantly $(\mathrm{P} \leq 0.05)$ for $23 \% \mathrm{CP}$ within soybean source. However, this un-trended finding could be due to the short period of egg recording. Moreover, the source effect was insignificant $(\mathrm{P}>0.05)$. In general, the FCR values of this experiment were relatively high and resulted in a bad trend. Similarly, Salih, 2016, reported that the means of nine quail genotypes fed $15.7 \%$ soybean meal crude protein in laying period resulted in high feed conversion ratio of laying period.

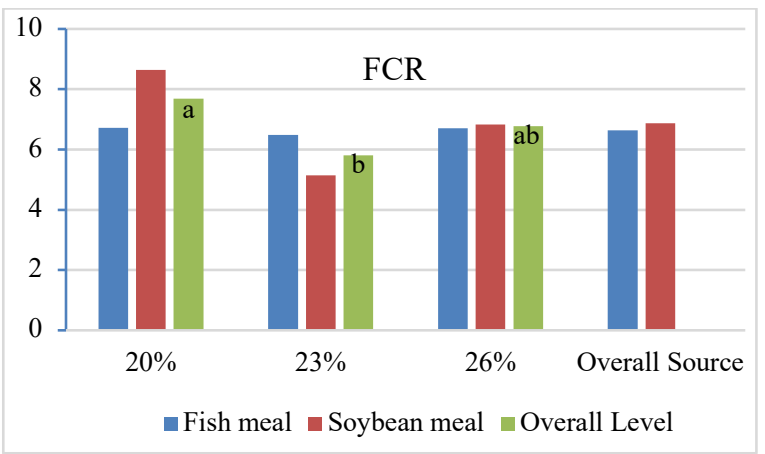

Figure 4. Feed conversion as affected by protein source and levels (for two successive weeks)

\section{CONCLUSION}

It could be concluded from the present research that neither source of protein nor its level play a vital role in early egg yield nor egg quality of J. quail. Moreover, in general such birds consume a high quantity of feed irrespective to the source of the used CP.

\section{REFERENCES}

Albino, L.F.T. and Barreto, S.L.T. 2003. Criação de codornas para produção de ovose carne. Viçosa:Aprenda Fácil: 268.

Barreto, S.L.T., Quirino, B.J.S., Brito, C.O., Umigi, R.T., Araujo, M.S., Rocha, T.C. and Pereira, C.G. 2007. Efeitos de níveis nutricionais de energia sobre o desempenho e a qualidade de ovos de codornas européias na faseinicial de postura. Revista Brasileira de Zootecnia 36(1): 86- 93.

Berwary, M.S., Oramari, R.A. and Hussen, S.H. 2015. Correlated response to selection for residual feed intake in Japanese quail (Coturnix coturnix japonica). Journal of University of Duhok 18(1): 135-144.

Cho, Y. M., Shin, I. S. and Yang, C. J. 2004. Effects of Feeding Dried Leftover Food on Productivity of Laying Hens. Department of Animal Science \& Technology, Sunchon National University, Suncheon 540-742, Korea.

Church, D.C. 1991.The nutrients, their metabolism, and feeding standards. In: Church, D.C. (ed.) Livestock Feeds and Feeding, 3rd edn. Prentice Hall. Englewood Cliffs, New Jersey.

Dahouda,M., Adjolohoun, S., Montchowul, E.H., Senou, M. and Hounsou, N. M. D. 2013. Growth Performance Of Quail (Coturnix coturnix) Fed On Diet Containing Either Animal Or Vegetable Protein Sources. International J. Of Poult. Sci.12(7):398-400

Duncan, D.B. 1955. Multiple range and multiple F tests. Biometrics, 11: $1-42$.

Eishu, R.i., Sato,K., Oikawa, T., kunieda, T. and Uchida, H. 2005. Effects of Dietary Protein Levels on Production and Characteristics of Japanese Quail Eggs.The J. Of Poult. Sci. 42:130-139.

Fernando, G.P.C., Nobre, I.S., G.Silva, L.P., Goulart, C.C., Figueiredo, D.F., Gunawardana, P., Roland, S. D.A. and Bryant M.M. 2008. Effect of energy and protein on performance, egg components, egg solids, egg quality and profits in molted HyLine W36 Hens. J. of Applied Poult. Res.17:390-397.

Gunawardana, P., Roland, D.A. and Bryant, M.M. 2008. Effect of energy and protein on performance, egg components, egg solids, egg quality and profits in molted hy-line W-36 hens. J. of Applied Poult. Res.17: 432-439. 
Khajali,F ., Khoshouie, E.A., Dehkordi, S.K. and Hematian, M. 2008. Production performance and egg quality of Hy-line W36 laying hens fed reduced-protein diets at a constant total sulfur amino acid: Lysine ratio. J. Applied Poult. Res. 17: 390397.

Khurshid, A., Farooq, M., Durranit, F.R. and Sarbil, K. 2003. Predicting egg weight, of Japanese quails, using varies egg traits and regressors. International J. of Poult. Sci. 2(2): 164.167.

Kingori, A.M., Tuitoek, J.K., Muiruri, H.K. and Wachira, A.M. 2010. Effect of dietary crude protein levels on egg production, hatchability and post-hatch offspring performance of Indigenous chickens. International J. of Poult. Sci. 9(4):324329.

Minoguchi, N., Ohguchi, H., Yamamoto, R., Saito, T. and Mizuno, K. 2000. The effect of reducing in dietary crude protein on the laying performance of Japanese quail, using phase feeding system. Research Bulletin Aichi Agricultural Research Center 32:241-246.

MohitiAsli, M., Shivazad, M., Zaghari, M., Rezaizan, M., Aminzadeh, S. and Mateos, G.G. 2012. Effects of feeding regimen, fiber inclusion and crude protein content of the diet on performance and egg quality and hatchability of eggs of broiler breeder hens. Poult. Sci. 91:3097-3106.

Mori, C., Garcia, E.A., Pavan, A.C., Piccinin, A., Scherer, M.R. and Pizzolante, C.C. 2005. Desempenhoe qualidade dos ovos de codorna de quarto grupos genéticos. Revista Brasileira de Zootecnia 34(3): 864- 869.

National Research Council 1985. Nutrient requirements of poultry. $2^{\text {ed }}$ revised edition. National Academy press.22. Washington, D.C.

Narushin, V.G. and Romanov, M.N. 2002. Egg physical characteristics and hatchability. World's J. of Poult. Sci. 58: 297-303.
Ohguchi, H., Kato, S., Goto, T. and Nagata, S.1997.The effect of low protein diets on growth, laying performance and nitrogen excretion of Japanese quail. Research Bulletin Aichi Agricultural Research Center 29: 349-353.

Saleh, J. H. and Hussen, S.H. 2018. Genetic evaluation of three quail lines/ by full diallel cross design II- Egg production. Journal of University of Duhok (Agri. and Vet. Sciences) 22(1): 243251.

Saleh, J. H. 2016. Genetic evaluation of three quail lines in a full diallel cross. M.Sc. thesis, Dept. of Animal Production, University of Duhok, Kurdistan Region, Iraq.

SAS Institute. 2014. Statistical Analysis System (SAS, institute, Inc.), version 9.4. Cary NC, USA.

Shim, K.F. and Vohra, P.1984. A review of the nutrition of Japanese quail. World's Poult. Sci. 40:261-274.

Shim, M. Y., Song, E., Billard , L., Aggrey , S. E., Pesti , G. M. and Sodsee, P. 2013. Effects of balanced dietary protein levels on egg production and egg quality parameters of individual commercial layers. Poult. Sci. 92 :2687-2696.

Song, K.T., Choi, S.H. and OH, H.R. 2000. A Comparison of Egg Quality of Pheasant, Chukar, Quail and Guinea Fowl Asian Australasian J. of Anim. Sci.Vol. 13: 986 -990.

Wolc, A. and Olori, V.E. 2009. Genetics of Hatchabilityegg Quality from the Perspective of a Chick 6thEuropean Poultry Genetics Symposium, World Poultry Science Association, Bedlewo, Poland.

Wilson, W.O., Abbot, U.K. and Abplanal,p. H.1961.Evaluation of Coturnix (Japanese Quail) as pilot animal for poultry. Poult. Sci. 40:651-657.

Yalcin,S., Ilyas, O. B., Adnam, S. and Suzan, Y. 2007. The effects of dietary garlic powder on the performance of, egg traits and blood serum cholesterol of laying quails. Asian- Aust. J. Anim. Sci. 20(6):944-94 